\title{
GETTING BACK TO THE EVENT: COVID-19, ATTENDANCE AND PERCEIVED IMPORTANCE OF PROTECTIVE MEASURES
}

\author{
Marko Perić ${ }^{1}$, Nicholas Wise ${ }^{2}$, Reza Heydariª ${ }^{3}$ Mohammad Keshtidar ${ }^{3}$, and Janez Mekinc ${ }^{4}$ \\ ${ }^{1}$ University of Rijeka, Faculty of Tourism and Hospitality Management, Opatija, Croatia \\ ${ }^{2}$ Arizona State University, School of Community Resources and Development, Phoenix, AZ, USA \\ ${ }^{3}$ Faculty of Sports Sciences, Ferdowsi University of Mashhad, Mashhad, Iran \\ ${ }^{4}$ University of Primorska, Faculty of Tourism Studies - Turistica, Portorož, Slovenia
}

Original scientific paper

DOI $10.26582 / \mathrm{k} .53 .1 .2$

\begin{abstract}
:
Current COVID-19 realities have led to event disruptions, and new policies on who can be in event venues mean event organisers must consider and implement new protective measures for the safety and security of both active and passive participants. This empirical study focuses on event consumers and issues related to their intention to attend future sporting events and their perception of how important they find some of the safety-related protective measures when attending sporting events as spectators or competitors following the COVID-19 crisis. The results suggest that, once all restrictions on movement and sporting event attendance have been revoked, most of the respondents from one Middle East and two European countries will attend events in their home country within few weeks. In addition, the respondents from the country that experienced more severe consequences of the pandemic perceive all protective measures as more important than the respondents from countries that were less affected.
\end{abstract}

Key words: sporting events, Coronavirus pandemic, safety, spectators, competitors

\section{Introduction}

Events, especially sporting events, are important in society today (Wise \& Harris, 2019). Given the contemporary circumstances, after only a few months, the global outbreak of COVID-19 brought sporting events to an abrupt halt (Parnell, Widdop, Bond, \& Wilson, 2020). The cancellation of events due to the COVID-19 pandemic was to protect the health and safety of individuals and communities. As a result, the service economy, which includes sport and events, could do little other than see social and economic opportunities decline. Sport participation, business activity and related travel have thus been significantly affected (Gössling, Scott, $\&$ Hall, 2020). It seems the sport and events industries in general, relative to other industries, were less prepared to face the COVID-19 crisis (PwC's Sports Survey, 2020). Given a widespread contagion, COVID-19 has resulted in the cancellation or postponement of sporting events around the world, from local and regional sports events to national and international competitions (Australian Institute of Sport, 2020; Cooper \& Alderman, 2020). According to the Two Circles Sports Marketing Agency, the sports industry is expected to experi- ence $\$ 62$ billion (45\%) drop in 2020 revenue, and this economic detriment is due to the fact that half of 2020 events were or will be cancelled (Cohen, Robinson, \& Flint, 2020). Everyone seems affected by this virus, in a way that has plunged even the greatest human community in sports, the Olympics, into a haze of ambiguity (Toresdahl \& Asif, 2020).

Meanwhile, officials in many countries have been implementing different strategies to reduce the spread of COVID-19 by prescribing various protective measures including home quarantine, social distancing, reduction in working hours and work activities, or closure of schools and universities (Gössling, et al., 2020). There was no guarantee for a success, but many sporting events and professional leagues made plans to resume competition and bring attendees back to events. In fact, some professional leagues have already resumed (without or with a limited number of spectators inside the venue), with others to follow, but the overall stadium experience has significantly changed (DiFiori, et al., 2020; Majumdar \& Naha, 2020). While certain safety aspects such as technical features, security checks at entry and the presence of medical staff are already common practice (Kaplanidou \& Vogt, 2010; Kulczycki \& Halpenny, 2014; Perić, Vitezić, 
\& Đurkin Badurina, 2019; Pickering, Castley, Hill, $\&$ Newsome, 2010), current realities impose additional challenges to sporting event organisers who now have to consider and include new non-pharmaceutical protective measures for the safety and security of both active and passive participants.

While existing current safety measures are recommendations, although instructions are provided with justifications prescribed by health agencies' officials, the perspective of event consumers (competitors and spectators) has since been neglected among early studies on sporting events and COVID-19 research. This paper argues the need for such considerations and presents some preliminary data based on the importance of safety measures among sporting event attendees (both spectators and competitors) to get a sense of what measures are necessary before people will feel comfortable once again attending sporting events. To test this research design and gain international perspective, the researchers conduct a preliminary analysis in Croatia, Slovenia, and Iran. Croatia and Slovenia are two smaller populated neighbouring European countries that were very successful in the battle against COVID-19 during the first wave of pandemic, while Iran, a largely populated MiddleEast country suffered many casualties. To support this assertion, at the time of writing this paper, on $3^{\text {rd }}$ June 2020, Croatia and Slovenia recorded 2,246 and 1,477 COVID-19 cases and 103 and 109 deaths, respectively, while Iran recorded 157,562 cases and 7,942 deaths (https://www.worldometers. info/coronavirus/). Focusing on the importance of safety measures represents a transferable research approach that sporting governing bodies and event planning practitioners can consider to capture what safety measures attendees would like to see put in place before events resume. This study therefore focuses on event consumers and issues related to their intention to attend future sporting events and their perception of how important they find some of the safety-related protective measures when attending sporting events following the COVID-19 crisis.

\section{Methods}

\section{Questionnaire development}

The first part of the questionnaire encompassed participants' intentions to attend sporting events, sport preference, type of participation, event attending party and destination preference. The second part focused on respondents' perception of the importance of the COVID-19 related protective non-pharmaceutical measures when attending sporting events. Two authors developed the items based on the publicly available health agencies' recommendations and extant literature (e.g. Lee, Song, Bendle, Kim, \& Han, 2012; Xiao, et al., 2020). To refine and determine the wording of the question, items included in the questionnaire design were revised by other authors and two external experts in event management and security management so that interdisciplinary scope surrounding safety measures was realised. The final version included 17 items related to safety protection measures encompassing both personal protective (e.g. spectators wearing masks and gloves) and environmental (e.g. rigorous cleaning/disinfection techniques of the sporting facility will be implemented pre-event) measures, but respondents are left with an option to add any other safety measure they wished to identify. Respondents' perception was measured on a 5-point Likert-type scale where $1=$ not important at all, $2=$ of little importance, $3=$ of average importance, $4=$ important, and $5=$ very important/essential. The final part of the questionnaire comprised socio-demographic data. The questionnaire was initially prepared in English and then translated into the Croatian, Slovenian, and Persian Farsi languages. The Cronbach alpha was used to assess internal reliability of a scale measuring respondents' perception of the importance of the particular protective measures when attending sporting events for each language separately. The scale produced an alpha of .9535 for the Croatian sample, .9392 for Slovenian, and .9438 for the Iranian sample, which is highly acceptable (Burns \& Burns, 2008).

\section{Data collection}

Data for this preliminary analysis were collected from $25^{\text {th }}$ May to $3^{\text {rd }}$ June 2020. Due to importance of the topic as well as limited mobility and recommended social distancing, the questionnaire was distributed online. The link leading to the electronic version of the questionnaire was first sent to a convenience sample of individuals related to sport (either as spectators, competitors, or sports students) and then they were asked to forward it to their social networks and other contacts. Respondents' participation in the survey was voluntary and their responses remained anonymous. In total 1,091 valid responses were gathered, of which 320 in Croatia, 180 in Slovenia and 591 in Iran.

\section{Data analysis}

Due to the similar Croatian and Slovenian contexts regarding a relatively small damage suffered from Coronavirus, the respondents from these two countries were merged into one group, while the Iranian respondents remained in the other group. Descriptive statistics present respondents' characteristics and their preferences as well as their assessment of the importance of the safety-related protective measures when attending sporting events. Non-parametric Mann-Whitney U test was applied for identification of statistically significant 
differences between the two groups' perceptions of the importance of the safety-related protective measures when attending sporting events.

\section{Results}

Regarding demographic profile of this study's respondents (Table 1), most of them were male $(56 \%)$, aged around 30 years, employed $(45.37 \%)$ or students $(41.43 \%)$. These characteristics, as well as the fact that most of the respondents were highly educated, are quite common in such sport-related research contexts (e.g. Duglio \& Beltramo, 2017; Getz \& McConnell, 2014; Slavich, Dwyer, \& Rufer, 2018). It must also be noted that although Iran had in place a long-standing ban on the presence of women at the Iranian stadiums (which was lifted in 2019), many competitions are still held separately for women and men. In this survey, around $41 \%$ of the Iranian respondents were women.
Respondents' intention to attend a sporting event once all restrictions on movement and sporting event attendance have been revoked differ between groups: $56.80 \%$ in Croatia and Slovenia and $34.18 \%$ in Iran would not wait and would attend a sporting event as soon as possible, while $13-14 \%$ of the respondents never attend sporting events (Table 2). Out of those who will attend, most of the respondents in Croatia and Slovenia will attend as spectators, while in Iran as competitors. Football (soccer) events are the most popular type of events, but in Croatia and Slovenia respondents will attend these events mainly as spectators while in Iran as competitors, too. While in Croatia and Slovenia lot of respondents will also attend running (7.21\%) and cycling (5.81\%) events, volleyball emerged as very popular activity in Iran (within the category "other sports"). In general, selected sporting event will be held within their home country (91-95\%),

Table 1. Sample profile

\begin{tabular}{|c|c|c|c|c|c|c|c|}
\hline \multicolumn{2}{|c|}{ Dimension/variable } & \multicolumn{2}{|c|}{$\begin{array}{l}\text { Croatia \& Slovenia } \\
\qquad(\mathrm{N}=500)\end{array}$} & \multicolumn{2}{|c|}{$\begin{array}{c}\operatorname{Iran} \\
(\mathrm{N}=591)\end{array}$} & \multicolumn{2}{|c|}{$\begin{array}{c}\text { Total } \\
(\mathrm{N}=1,091)\end{array}$} \\
\hline & & $\mathrm{N}$ & $\%$ & $\mathrm{~N}$ & $\%$ & $\mathrm{~N}$ & $\%$ \\
\hline \multirow{2}{*}{ Gender } & Male & 265 & 53.00 & 346 & 58.54 & 611 & 56.00 \\
\hline & Female & 235 & 47.00 & 245 & 41.46 & 480 & 44.00 \\
\hline \multirow{5}{*}{ Education } & No education & 0 & 0.00 & 0 & 0.00 & 0 & 0.00 \\
\hline & Elementary & 2 & 0.40 & 30 & 5.08 & 32 & 2.93 \\
\hline & Secondary & 226 & 45.20 & 134 & 22.67 & 360 & 33.00 \\
\hline & University & 207 & 41.40 & 309 & 52.28 & 516 & 47.30 \\
\hline & Postgraduate & 65 & 13.00 & 118 & 19.97 & 183 & 16.77 \\
\hline \multirow{6}{*}{ Employment } & Public sector & 127 & 25.40 & 55 & 9.31 & 182 & 16.68 \\
\hline & Private sector & 188 & 37.60 & 125 & 21.15 & 313 & 28.69 \\
\hline & Unemployed & 20 & 4.00 & 43 & 7.28 & 63 & 5.77 \\
\hline & Retired & 19 & 3.80 & 6 & 1.02 & 25 & 2.29 \\
\hline & Student & 127 & 25.40 & 325 & 54.99 & 452 & 41.43 \\
\hline & Other & 19 & 3.80 & 37 & 6.26 & 56 & 5.13 \\
\hline \multirow{2}{*}{ Age } & \multirow{2}{*}{ Average age } & \multicolumn{2}{|c|}{ years } & \multicolumn{2}{|c|}{ years } & \multicolumn{2}{|c|}{ years } \\
\hline & & \multicolumn{2}{|c|}{37.53} & \multicolumn{2}{|c|}{25.81} & \multicolumn{2}{|c|}{31.18} \\
\hline
\end{tabular}

Table 2. Intention to attend a sporting event

\begin{tabular}{|c|c|c|c|c|c|c|}
\hline \multirow{2}{*}{$\begin{array}{l}\text { Once all restrictions on movement and } \\
\text { sporting event attendance have been } \\
\text { revoked, how long will you wait to attend } \\
\text { a sporting event? }\end{array}$} & \multicolumn{2}{|c|}{$\begin{array}{l}\text { Croatia \& Slovenia } \\
\qquad(N=500)\end{array}$} & \multicolumn{2}{|c|}{$\begin{array}{c}\text { Iran } \\
(\mathrm{N}=591)\end{array}$} & \multicolumn{2}{|c|}{$\begin{array}{c}\text { Total } \\
(\mathrm{N}=1,091)\end{array}$} \\
\hline & $\mathrm{N}$ & $\%$ & $\mathrm{~N}$ & $\%$ & $\mathrm{~N}$ & $\%$ \\
\hline $\begin{array}{l}\text { I will not wait; I will attend immediately } \\
\text { (within a week) }\end{array}$ & 284 & 56.80 & 202 & 34.18 & 486 & 44.55 \\
\hline 2-4 weeks & 60 & 12.00 & 114 & 19.29 & 174 & 15.95 \\
\hline 1-2 months & 42 & 8.40 & 117 & 19.80 & 159 & 14.57 \\
\hline $3-6$ months & 28 & 5.60 & 46 & 7.78 & 74 & 6.78 \\
\hline Over 6 months & 16 & 3.20 & 35 & 5.92 & 51 & 4.67 \\
\hline $\begin{array}{l}\text { I never attend sporting events (and I will } \\
\text { not attend future sporting events) }\end{array}$ & 70 & 14.00 & 77 & 13.03 & 147 & 13.47 \\
\hline
\end{tabular}


Table 3. Respondents' preferences regarding sporting event attendance

\begin{tabular}{|c|c|c|c|c|c|c|}
\hline \multirow{2}{*}{ Question/variable } & \multicolumn{2}{|c|}{$\begin{array}{l}\text { Croatia \& Slovenia } \\
\qquad(\mathrm{N}=430)\end{array}$} & \multicolumn{2}{|c|}{$\begin{array}{c}\text { Iran } \\
(\mathrm{N}=514)\end{array}$} & \multicolumn{2}{|c|}{$\begin{array}{c}\text { Total } \\
(\mathrm{N}=944)\end{array}$} \\
\hline & $\mathrm{N}$ & $\%$ & $\mathrm{~N}$ & $\%$ & $\mathrm{~N}$ & $\%$ \\
\hline \multicolumn{7}{|c|}{ What will be the first type of sporting event you will attend once restrictions have ended? } \\
\hline Football/Soccer event & 209 & 48.60 & 146 & 28.40 & 355 & 37.61 \\
\hline Basketball event & 24 & 5.58 & 19 & 3.70 & 43 & 4.56 \\
\hline Swimming event & 6 & 1.40 & 75 & 14.59 & 81 & 8.58 \\
\hline Athletics event & 9 & 2.09 & 15 & 2.92 & 24 & 2.54 \\
\hline Tennis tournament & 12 & 2.79 & 13 & 2.53 & 25 & 2.65 \\
\hline Running event & 31 & 7.21 & 0 & 0.00 & 31 & 3.28 \\
\hline Cycling event & 25 & 5.81 & 23 & 4.47 & 48 & 5.08 \\
\hline Weightlifting event & 5 & 1.16 & 12 & 2.33 & 17 & 1.80 \\
\hline Local/traditional sporting event & 67 & 15.58 & 10 & 1.95 & 77 & 8.16 \\
\hline Other sports & 42 & 9.77 & 201 & 39.11 & 243 & 25.74 \\
\hline \multicolumn{7}{|c|}{ My participation to the sporting event selected in Q2 will be as a: } \\
\hline Competitor & 88 & 20.47 & 421 & 81.91 & 509 & 53.92 \\
\hline Spectator & 342 & 79.53 & 93 & 18.09 & 435 & 46.08 \\
\hline \multicolumn{7}{|c|}{ Who do you plan to be accompanied with while attending the selected sporting event: } \\
\hline I will attend alone & 33 & 7.67 & 121 & 23.54 & 154 & 16.31 \\
\hline With a family & 93 & 21.63 & 29 & 5.64 & 122 & 12.92 \\
\hline With a partner & 57 & 13.26 & 17 & 3.31 & 74 & 7.84 \\
\hline With friends & 247 & 57.44 & 347 & 67.51 & 594 & 62.92 \\
\hline \multicolumn{7}{|c|}{ The selected sporting event to which you plan to attend is located: } \\
\hline In my home country & 394 & 91.63 & 488 & 94.94 & 882 & 93.43 \\
\hline Abroad & 36 & 8.37 & 26 & 5.06 & 62 & 6.57 \\
\hline
\end{tabular}

and respondents will be accompanied with their friends (Table 3).

Table 4 suggests that respondents' perception of the importance of the safety-related protective measures when attending sporting events vary depending the group. In Croatia and Slovenia, respondents perceived all the measures as less important than did respondents in Iran. Availability of hand sanitizers, sanitization of seats before sitting, cleaning and disinfection of a sport facility and contactless/ automated paying for tickets and services are identified as of above the average importance in Croatia and Slovenia. The Iranian respondents perceive all the measures as important, especially rigorous cleaning and disinfection of a sport facility, availability of hand sanitizers, automated ticketing as well as keeping minimum distance between spectators. When it comes to social distancing, it should be noted that women at the Iranian stadiums, due to special socio-cultural values, reside in a special part of the grandstand $(10 \%$ of the total stadium space is usually reserved for women), where men do not have the right of access. Mann-Whitney $\mathrm{U}$ test confirmed what has been assumed, that is, that there were significant differences in perception of all safety-related protective measures between
Croatia and Slovenia (group 1) and Iran (group 2) (36744.00 $\leq \mathrm{U} \leq 76821.50, \mathrm{p}=0.00000$ ). Respondents also suggested some measures such as utilization of disinfection tunnels for spectators and staff before entering the sports event or proper air conditioning and ventilation at the competition venue.

\section{Discussion and conclusions}

Being aware of a limitation that the two samples differ to an extent (the Iranian respondents were younger and more frequently athletes and/or students), this study showed that most respondents will attend sporting events in their home countries within few weeks after all restrictions on movement and sporting event attendance will be lifted. This is in line with the study of spectators in Belarus Premier League during the COVID-19 crisis (Reade, Schreyer, \& Singleton, 2020) and provides a breath of optimism for the event and sports tourism markets, which was considered to be one of the hardest hit tourism subsectors (Gössling, et al., 2020). Still, this does not mean that organisations' existing business models will stay the same; many will have to adapt and innovate focusing on new strategies to generate revenue such as tick- 
Table 4. Perception of the importance of the safety-related protective measures when attending sporting events

\begin{tabular}{|c|c|c|c|c|c|c|c|c|c|c|}
\hline \multirow{2}{*}{$\begin{array}{l}\text { Please indicate } \\
\text { how important you } \\
\text { consider each of } \\
\text { the following safety } \\
\text { protective measures at } \\
\text { a sporting venue: }\end{array}$} & \multicolumn{2}{|c|}{$\begin{array}{l}\text { Croatia \& } \\
\text { Slovenia }\end{array}$} & \multicolumn{2}{|c|}{ Iran } & \multicolumn{2}{|c|}{ Total } & \multirow{2}{*}{$\begin{array}{l}\text { Mann- } \\
\text { Whitney } \\
\text { U }\end{array}$} & \multirow{2}{*}{ z } & \multirow{2}{*}{$\mathrm{p}$} & \multirow{2}{*}{$\begin{array}{l}\text { Mean } \\
\text { Rank }^{\mathrm{a}}\end{array}$} \\
\hline & M & SD & M & SD & M & SD & & & & \\
\hline $\begin{array}{l}\text { Availability of hand } \\
\text { sanitizer }\end{array}$ & 3.34 & 1.29 & 4.40 & 0.91 & 3.91 & 1.22 & 76821.50 & -14.443971 & $.0001^{*}$ & $1<2$ \\
\hline $\begin{array}{l}\text { Working staff wearing } \\
\text { masks and gloves }\end{array}$ & 2.89 & 1.30 & 4.29 & 0.94 & 3.65 & 1.32 & 60186.50 & -17.497281 & $.0001^{*}$ & $1<2$ \\
\hline $\begin{array}{l}\text { Spectators wearing } \\
\text { masks and gloves }\end{array}$ & 2.51 & 1.25 & 4.30 & 0.97 & 3.48 & 1.42 & 43492.50 & -20.724585 & $.0001^{*}$ & $1<2$ \\
\hline $\begin{array}{l}\text { Staff/employees will } \\
\text { have temperature } \\
\text { checked before } \\
\text { starting shift }\end{array}$ & 2.73 & 1.29 & 4.26 & 0.94 & 3.56 & 1.35 & 55027.00 & -18.457956 & $.0001^{*}$ & $1<2$ \\
\hline $\begin{array}{l}\text { Spectators will have } \\
\text { temperature checked } \\
\text { before entry }\end{array}$ & 2.55 & 1.29 & 4.22 & 1.00 & 3.46 & 1.41 & 49891.00 & -19.422494 & $.0001^{*}$ & $1<2$ \\
\hline Automated ticketing & 3.10 & 1.31 & 4.41 & 0.87 & 3.81 & 1.27 & 62161.50 & -17.273795 & $.0001^{*}$ & $1<2$ \\
\hline $\begin{array}{l}\text { Security searches } \\
\text { upon entry will be } \\
\text { contactless only }\end{array}$ & 2.96 & 1.25 & 4.23 & 0.88 & 3.65 & 1.24 & 63895.00 & -16.734345 & $.0001^{*}$ & $1<2$ \\
\hline $\begin{array}{l}\text { Number of spectators } \\
\text { will be limited }\end{array}$ & 2.83 & 1.29 & 4.18 & 0.97 & 3.56 & 1.31 & 62134.00 & -17.035986 & $.0001^{*}$ & $1<2$ \\
\hline $\begin{array}{l}\text { Minimum distance } \\
\text { between spectators } \\
\text { will be enforced }\end{array}$ & 2.73 & 1.26 & 4.43 & 0.82 & 3.65 & 1.34 & 42642.00 & -21.019835 & $.0001^{*}$ & $1<2$ \\
\hline $\begin{array}{l}\text { Chairs in the stands } \\
\text { will be separated for } \\
\text { social distancing }\end{array}$ & 2.66 & 1.28 & 4.31 & 0.92 & 3.55 & 1.37 & 47840.00 & -19.887787 & $.0001^{*}$ & $1<2$ \\
\hline $\begin{array}{l}\text { Seats will be sanitized } \\
\text { by venue staff just } \\
\text { before an attendee } \\
\text { sits in their seat }\end{array}$ & 3.25 & 1.32 & 4.39 & 0.87 & 3.87 & 1.24 & 72762.00 & -15.191533 & $.0001^{*}$ & $1<2$ \\
\hline $\begin{array}{l}\text { Food and beverage } \\
\text { services/options will } \\
\text { be limited }\end{array}$ & 2.30 & 1.19 & 4.22 & 0.95 & 3.34 & 1.43 & 36744.00 & -21.949489 & $.0001^{*}$ & $1<2$ \\
\hline $\begin{array}{l}\text { Spectators allowed } \\
\text { in common areas } \\
\text { will be limited (i.e. } \\
\text { restaurants, bars, } \\
\text { toilets, etc.) }\end{array}$ & 2.83 & 1.26 & 4.20 & 0.92 & 3.57 & 1.28 & 59452.00 & -17.582573 & $.0001^{*}$ & $1<2$ \\
\hline $\begin{array}{l}\text { Paying for all services } \\
\text { will be contactless }\end{array}$ & 3.06 & 1.31 & 4.24 & 0.91 & 3.70 & 1.26 & 72294.00 & -15.113253 & $.0001^{*}$ & $1<2$ \\
\hline $\begin{array}{l}\text { Rigorous cleaning/ } \\
\text { disinfection } \\
\text { techniques of the } \\
\text { sporting facility will } \\
\text { be implemented } \\
\text { pre-event }\end{array}$ & 3.33 & 1.30 & 4.49 & 0.75 & 3.96 & 1.19 & 69780.00 & -15.922891 & $.0001^{*}$ & $1<2$ \\
\hline $\begin{array}{l}\text { Additional cleaning/ } \\
\text { disinfection of the } \\
\text { sport facility will } \\
\text { happen immediately } \\
\text { post-event }\end{array}$ & 3.19 & 1.32 & 4.51 & 0.77 & 3.90 & 1.24 & 61686.50 & -17.526025 & $.0001^{*}$ & $1<2$ \\
\hline $\begin{array}{l}\text { The venue will be } \\
\text { vacant for at least a } \\
\text { day/night between } \\
\text { events }\end{array}$ & 2.62 & 1.35 & 4.08 & 1.06 & 3.41 & 1.40 & 62929.00 & -16.801226 & $.0001^{*}$ & $1<2$ \\
\hline Total average & 2.87 & 1.32 & 4.30 & 0.92 & 3.65 & 1.33 & & & & \\
\hline
\end{tabular}

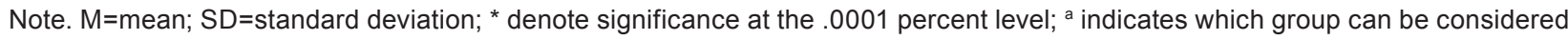
as having the higher mean rank (1=Croatia \& Slovenia; $2=$ Iran). 
eting strategies, digitalisation strategies, and media involvement (PwC's Sports Survey, 2020; Reade \& Singleton, 2020).

Taking this work forward and expanding on this preliminary study is a chance to develop some further hypotheses. For instance, based on the respondents' intention to attend sporting events, their perceptions of health risks related to attending sporting events seems to be low. The lower perceived risks usually result in higher intention to (re)visit a destination or attend an event (Karl, 2018; Reade, et al., 2020; Reade \& Singleton, 2020; Yang, KhooLattimore, \& Arcodia, 2017) but this study did not examine this relationship directly. However, this study focused on the respondents' perception of importance of the safety-related protective measures when attending sporting events suggesting that the Iranian respondents found safety-related protective measures more important than did their counterparts in Croatia and Slovenia. The relationship between the health risk perception and readiness to implement non-pharmaceutical interventions was found positive in previous studies (Lee, et al., 2012), so we can argue that higher importance of the safety-related protective measures when attending sporting events expressed by Iranians could be a result of a higher level of perceived health risks. Indeed, Iran suffered more during the COVID-19 pandemic than Croatia or Slovenia and the difference between the two groups can partly be a consequence of this exogenous factor. Accordingly, experiencing more severe consequences of the pandemic (and perceived risk that could be a subject of further research) could affected the Iranian respondents to be increasingly cautious and to expect rigor safetyrelated protective measures at sporting events.

While this study examined the differences between the two groups belonging to different cultural backgrounds and country contexts in their perception of safety-related protective measures at sporting events, future testing should show whether the respondents' perception depend on sociodemographic and travel-related attributes such as age, gender, education, employment, preferences regarding sports, type of participation, or travel party. In addition, as has been argued by Alexandris, Theodorakis, Kaplanidou and Papadimitriou (2017) and Risitano, Tutore, Sorrentino and Quintano (2017), each event or country is specific and it would be important for future studies to consider these particularities when proposing and/ or analysing safety-related protective measures.

Building on Evans et al. (2020) and Parnell et al. (2020), this study implies that attending sporting events will continue to play an important role in the future, despite the current disruption to larger scale social gatherings. This is especially true for football (soccer), which is fundamentally a networked game with many stakeholders involved in delivering and consuming a football game (Bond, Widdop, \& Chadwick, 2018; Parnell, et al., 2020). Moreover, football is a sport with great revenue growth potential and limiting or eliminating fans will have quite an extensive economic impact (PwC's Sports Survey, 2020). Further, this study shed some light to what changes event attendees would like to see and what were their concerns regarding post COVID-19 sporting events. Regardless the limited evidence on the effectiveness of some environmental and/ or personal protective measures in reducing infectious diseases (Xiao, et al., 2020), Gössling et al. (2020) predict that social distancing will remain a key part of safety-related protective strategies in preventing the pandemic in months that follow. This study pointed to several important safety-related protective measure in addition to social distancing (e.g. hand hygiene and rigorous cleaning/disinfection). Therefore, this study's findings are largely relevant for event practice, especially when many relevant stakeholders have correctly assumed the second wave of coronavirus is continuing to show challenging times ahead for the sport and tourism industries, but with a chance to better prepare given more knowledge of the virus and its spread (Cacciapaglia, Cot, \& Sannino, 2020; Ghanbari, 2020; Middleton, Lopes, Michelson, \& Reid, 2020), but despite this, safety approaches will be needed for some time, even in post-COVID-19 period. In addition to proper and consistent implementation of safety-related protective measures, prescribed by world or national health agencies and sport associations, event organisers can ensure even higher level of safety for all attendees in (post)COVID-19 environment. Regardless of the degree to which countries are affected by the spread of COVID-19, event consumers will appreciate these efforts as safety is still at the top of persons' individual values and priorities. 


\section{References}

Alexandris, K., Theodorakis, N.D., Kaplanidou, K., \& Papadimitriou, D. (2017). Event quality and loyalty among runners with different running involvement levels: The case of "The Alexander the Great" International Marathon. International Journal of Event and Festival Management, 8(3), 292-307. doi: 10.1108/IJEFM-08-2016-0057

Australian Institute of Sport (AIS). (2020). Framework for rebooting sport in Covid-19 environment. Retrieved May 30, 2020 from: https://www.mtba.org.au/wp-content/uploads/35845_AIS-Framework-for-rebooting-sport_FA.pdf

Bond, A., Widdop, P., \& Chadwick, S. (2018). Football's emerging market trade network: Ego network approach to world systems theory. Managing Sport and Leisure, 23(1-2), 70-91. doi: 10.1080/23750472.2018.1481765

Burns, R.P., \& Burns, R.A. (2008). Business research methods and statistics using SPSS. London: SAGE Publications.

Cacciapaglia, G., Cot, C., \& Sannino, F. (2020). Second wave COVID-19 pandemics in Europe: A temporal playbook. Scientific Reports, 10, 15514. doi: 10.1038/s41598-020-72611-5

Cohen, B., Robinson. J., \& Flint, J. (2020). Sports industry reels from Coronavirus fallout. The Wall Street Journal (Online edition 29 March, 2020). Retrieved May 30, 2020 from: https://www.wsj.com/articles/sports-industryreels-from-coronavirus-fallout-11585517192

Cooper, J.A., \& Alderman, D.H. (2020). Cancelling March Madness exposes opportunities for a more sustainable sports tourism economy. Tourism Geographies, doi: 10.1080/14616688.2020.1759135

DiFiori, J.P., Green, G., Meeuwisse, W., Putukian, M., Solomon, G.S., \& Sills, A. (2020). Return to sport for North American professional sport leagues in the context of COVID-19. British Journal of Sports Medicine, Epub ahead of print doi: 10.1136/bjsports-2020-103227

Duglio, S., \& Beltramo, R. (2017). Estimating the economic impacts of a small-scale sport tourism event: The case of the Italo-Swiss mountain trail CollonTrek. Sustainability, 9(3), 343. doi: 10.3390/su9030343

Evans, A.B., Blackwell, J., Dolan, P., Fahlén, J., Hoekman, R., Lenneis, V., McNarry, G., Smith, M., \& Wilcock, L. (2020). Sport in the face of the COVID-19 pandemic: Towards an agenda for research in the sociology of sport. European Journal for Sport and Society, 17(2), 85-95, doi: 10.1080/16138171.2020.1765100

Getz, D., \& McConnell, A. (2014). Comparing trail runners and mountain bikers: Motivation, involvement, portfolios, and event-tourist careers. Journal of Convention and Event Tourism, 15(1), 69-100. doi:10.1080/15470148.201 3.834807

Ghanbari, B. (2020). On forecasting the spread of the COVID-19 in Iran: The second wave. Chaos, Solitons and Fractals, 140, 110176. doi: 10.1016/j.chaos.2020.110176

Gössling, S., Scott, D., \& Hall, C.M. (2020): Pandemics, tourism and global change: A rapid assessment of COVID19. Journal of Sustainable Tourism, 29(1), 1-20. doi: 10.1080/09669582.2020.1758708

Kaplanidou, K., \& Vogt, C. (2010). The meaning and measurement of a sport event experience among active sport tourists. Journal of Sport Management, 24(5), 544-566. doi: 10.1123/jsm.24.5.544

Karl, M. (2018). Risk and uncertainty in travel decision-making: Tourist and destination perspective. Journal of Travel Research, 57(1), 129-146. doi: 10.1177/0047287516678337

Kulczycki, C., \& Halpenny, E.A. (2014). Sport cycling tourists' setting preferences, appraisals and attachments. Journal of Sport and Tourism, 19(2), 169-197. doi: 10.1080/14775085.2015.1070741

Lee, C-K., Song, H-J., Bendle, L.J., Kim, M-J, \& Han, H. (2012). The impact of non-pharmaceutical interventions for 2009 H1N1 influenza on travel intentions: A model of goal-directed behavior. Tourism Management, 33, 89-99. doi: 10.1016/j.tourman.2011.02.006

Majumdar, M., \& Naha, S. (2020). Live sport during the COVID-19 crisis: Fans as creative broadcasters. Sport in Society. doi: 10.1080/17430437.2020.1776972

Middleton, J., Lopes, H., Michelson, K., \& Reid, J. (2020). Planning for a second wave pandemic of COVID-19 and planning for winter. International Journal of Public Health, 65, 1525-1527. doi: 10.1007/s00038-020-01455-7

Parnell, D., Widdop, P., Bond, A., \& Wilson, R. (2020). COVID-19, networks and sport. Managing Sport and Leisure. doi: 10.1080/23750472.2020.1750100

Perić, M., Vitezić, V., \& Đurkin Badurina, J. (2019). Business models for active outdoor sport event tourism experiences. Tourism Management Perspectives, 32, 100561. doi: 10.1016/j.tmp.2019.100561

Pickering, C., Castley, J.G., Hill, W., \& Newsome, D. (2010). Environmental, safety and management issues of unauthorised trail technical features for mountain bicycling. Landscape and Urban Planning, 97(1), 58-67. doi: 10.1016/j.landurbplan.2010.04.012

PwC's Sports Survey. (2020). Sports industry: System rebooting. PricewaterhouseCoopers AG. Retrieved December 12, 2020 from: https://www.pwc.ch/en/publications/2020/PwCs-Sports-Survey-2020.pdf

Reade, J., Schreyer, D., \& Singleton, C. (2020). Stadium attendance demand during the Covid-19 crisis: Early empirical evidence from Belarus. Discussion Paper No. 2020-20. Retrieved December 12, 2020 from: http://www.reading. ac.uk/web/files/economics/emdp202020.pdf

Reade, J., \& Singleton, C. (2020). Demand for public events in the COVID-19 pandemic: A case study of European football (May 1, 2020). European Sport Management Quarterly, e-pub ahead of print. doi: 10.2139/ssrn.3558861 
Risitano, M., Tutore, I., Sorrentino, A., \& Quintano, M. (2017). The influence of tourists' national culture on their behaviours in a sport mega-event. International Journal of Culture, Tourism and Hospitality Research, 11(2), 193-210. doi: 10.1108/IJCTHR-07-2015-0077

Slavich, M.A., Dwyer, B., \& Rufer, L. (2018). An evolving experience: An investigation of the impact of sporting event factors on spectator satisfaction. Journal of Global Sport Management, 3(1), 79-98. doi: 10.1080/24704067.2017.1411162

Toresdahl, B.G., \& Asif, I.M. (2020). Coronavirus disease 2019 (COVID-19): Considerations for the competitive athlete. Sports Health: A Multidisciplinary Approach, 12(3), 221-224. doi: 10.1177/1941738120918876

Wise, N., \& Harris, J. (Eds.) (2019). Events, places and societies. London: Routledge.

Xiao, J., Shiu, E.Y.C., Gao, H., Wong, J.Y., Fong, M.W., Ryu, S., \& Cowling, B.J. (2020). Nonpharmaceutical measures for pandemic influenza in nonhealthcare settings-Personal protective and environmental measures. Emerging Infectious Diseases, 26(5), 967-975. doi: 10.3201/eid2605.190994

Yang, E.C.L., Khoo-Lattimore, C., \& Arcodia, C. (2017). A systematic literature review of risk and gender research in tourism. Tourism Management, 58, 89-100. doi: 10.1016/j.tourman.2016.10.011

Submitted: June 24, 2020

Accepted: December 22, 2020

Published Online First: February 16, 2021

Correspondence to:

Marko Perić, Ph.D.

University of Rijeka, Faculty of Tourism and

Hospitality Management, Opatija, Croatia

Phone: +38551294191

Fax: +38551291965

E-mail: markop@fthm.hr 